\title{
The Relation Between Lifelong Learning Tendency and Achievement Motivation
}

\author{
Emrullah Yilmaz ${ }^{1}$, Hüseyin Kaygin ${ }^{1}$ \\ ${ }^{1}$ Bartın University, Turkey \\ Correspondence: Emrullah Yilmaz, Bartın University, Turkey.
}

Received: October 3, 2017

Accepted: February 22, 2018

Online Published: March 27, 2018

doi:10.11114/jets.v6i3a.3141

URL: https://doi.org/10.11114/jets.v6i3a.3141

\begin{abstract}
The aim of this study is to reveal the relation between lifelong learning tendency and achievement motivation. The sampling of the study consisted of 570 prospective teachers attending a pedagogical formation course at two universities in Turkey in 2016. Relational screening model was used in the study and the data were collected through achievement focused motivation scale and lifelong learning tendency scale. The collected data were analysed using regression analysis on SPSS 22. As the findings suggest, there is a low, positive correlation $(\mathrm{r}=0.095)$ between prospective teachers' achievement motivation and lifelong learning tendency at $95 \%$ confidence interval. As for the correlation between lifelong learning tendency and the sub-dimensions of achievement motivation, lifelong learning tendency has a significant correlation with the expansion of objective $(\mathrm{r}=0,139)$, self-consciousness $(\mathrm{r}=0,128)$ and internal effect $(\mathrm{r}=0,089)$. However, it doesn't correlate significantly with external effect $(\mathrm{r}=-0,024)$. As the standardised regression coefficient $(\beta)$ indicates, the relative order of importance of predictor values on lifelong learning tendency is as follows; external effect, expansion of objective, self-consciousness and internal effect.
\end{abstract}

Keywords: relation, lifelong learning, achievement motivation

\section{Introduction}

The need to learn is inherent in all human beings as it is clearly observed in infancy and childhood period. In these periods, they usually ask questions resulting from their never-ending curiosity. They want to discover new things by using their physical and verbal abilities, moving from here and there and asking persistent questions to adults around them. As they grow older, especially soon after they start school, both parents and teachers usually complain that this need to learn seems to be waning. They expect their children's innate desire to learn to continue as long as they need it.

A lot of researchers work hard to find ways to keep people learning throughout their life. The fruitful process of learning that they have maintained since their birth shouldn't be intermitted. However, something is needed to trigger and sustain the process of learning. Lifelong learning and motivation, basically achievement motivation, are two concepts that play a significant role in encouraging people to learn throughout their life.

The term "lifelong learning" is not new. As Knapper and Cropley $(2000,1)$ point out "it is found in ancient writings, and was emphasized in the works of earlier European educational theorists such as Comenius and Matthew Arnold". The term has gained the peak of interest especially in late nineties with the activities of EU, UNESCO and OECD. Lifelong learning may be considered as an interdisciplinary term that has had a number of interpretations till today. Learning is an individual and group process that includes obtaining knowledge, comprehension or skill anywhere and anytime (Livingstone, 2010). Similarly, Commission of the European Communities (2001,9) defined lifelong learning as "all learning activity undertaken throughout life, with the aim of improving knowledge, skills and competencies within a personal, civic, social and/or employment-related perspective". Jarvis (2009) gives a long and detailed definition of lifelong learning and stresses that it is the combination of processes that take place throughout a lifetime. Jarvis puts main emphasis on a continual whole change and a biographical transformation experienced by a person throughout his/her lifespan.

Today lifelong learning has become a vital concept that shapes policies at national, international and even global level. Laal and Salamati $(2012,400)$ insert that lifelong learning not only contributes individuals to have knowledge, skills, values, etc. necessary for life but also helps communities to be more innovative and productive, through which new skills and ideas are generated by workers. Also, it enhances social inclusion, active citizenship and personal 
development along with competitiveness and employability (Coşkun and Demirel, 2010). The acquisitions of lifelong learners are listed by Knapler and Cropley (2000) as follows; planning and assessing their own learning, being an active learner instead of being passive, learning in both formal and informal settings, learning from their peers, teachers and mentors, integrating knowledge from different subject areas when required, and using different learning strategies for different situations. According to the Asia-Pacific Regional Forum for Lifelong Learning (2004), lifelong learning is based on forming a universal literacy including early childhood education, formal schooling, higher education, continuing education and distance education with the primary objective to "build a learning society to provide for today, while planning for tomorrow" (p.2). In brief, lifelong learning process provides individuals with the skills and knowledge they may need at anytime in their life by teaching them how to learn by themselves.

Motivation, on the other hand, is one of the concepts that are widely studied within the scope of psychology as it plays an important role in explaining human behaviour (Yılmaz, 2014). It is thus an inevitable component of education in general as education aims at changing human behaviour towards the desired direction. Educational psychology has come to the fore to make use of the findings of psychology in the field of education and motivation is one of the concepts that are frequently handled in this field. Slavin $(2012,286)$ defines motivation as "the influence of needs and desires on the intensity and direction of behaviour". Woolfolk $(2013,431)$ defines motivation as "an internal state that arouses, directs, and maintains behaviour". As is seen in these two citations, definitions of motivation may vary as it is not observed directly but inferred from behavioural indexes and it is hard to define it exactly (Schunk, 2012; Dereli and Acat, 2010).

Achievement is usually the main aim of education, so it is essential to study the correlation between achievement and motivation. It is thought that achievement leads to motivation or, as some scholars claim, motivation leads to achievement (Curwin, 2014). There is usually a mutual positive effect between achievement and motivation as supported by Guthrie, Wigfield and VonSecker (2000), who state that motivation and achievement influence each other. This is worth noting as the presence of one of these two constructs usually brings about the other. A great deal of research assert that motivation predicts achievement (Gagne and Pere, 2001; Steinmayr and Spinath, 2009; Bakar et al., 2010; Semerci and Duman, 2013). As stated by Martin (2012, 670) "motivational theories have proliferated in psychology and a whole field is dedicated to Achievement Motivation (AM), which asks why a person engages and persists in tasks or activities that lead to success or, alternatively, failure". Achievement motivation is a multidimensional, complex concept as is the case with motivation (Story et al. 2009). Achievement motivation has been employed to explain individuals' achievement-motivated behaviour or the corresponding outcome with respect to motives" (Heckhausen and Heckhausen, 2008). As Schunk $(2012,358)$ puts it "the study of achievement motivation is central to education and learning". Achievement motivation is defined by Kaur $(2013,409)$ as "the tendency to strive for success or the attainment of a desirable goal". Bakar et al. $(2010,4906)$ describe achievement motivation briefly as "one's inner drive to achieve". When the explanations above are taken into consideration, it can be said that achievement motivation refers to all activities of individuals aiming at achieving a desirable goal.

There are some studies in literature trying to find the relationship between lifelong learning and motivation, however, there are almost no studies on the relationship between achievement motivation and lifelong learning, which may result from the fact that these two constructs are restricted in nature compared to more general terms, learning and motivation. So, this study aims at filling the gap in this issue and starting a discussion focusing on these two constructs and their predictability.

\section{Method}

Relational screening model was used in the study and the sampling of the study consisted of 570 prospective teachers attending a pedagogical formation course at two universities in Turkey in 2016. No sampling method was employed as all the subjects were included in the study. The data were collected via achievement focused motivation scale (AFMS) (Semerci, 2010) and lifelong learning tendency scale (LLTS) (Coşkun and Demirel, 2010). In its development phase, achievement focused motivation scale was applied to 827 subjects at five universities in Turkey to determine their achievement motivation levels. As a result of the factor analysis, four sub-factors (external effect, internal effect, expansion of objective and self-consciousness) were found. It was observed that total variance was $37.910 \%$. Item total correlations ranged between 0.36-0.58. 49 data pairs were formed in the study and test-retest correlation was 0.977 $(\mathrm{p}<0.01)$. The correlation between subjects' scores from the two halves of the scale was $0.895(\mathrm{p}<0.01)$. Cronbach's Alpha coefficient was found 0.896 (total number of items:35).

Lifelong learning tendency scale was developed by Coşkun and Demirel in 2010 in order to determine the lifelong learning tendencies of university students. The scale was administered to 642 university students attending two universities in Turkey and explanatory factor analysis was conducted to determine the construct validity. The final scale consisted of 27 items in total and four sub-dimensions (motivation, perseverance, lack of regulating learning, and lack 
of curiosity) were defined. The Cronbach's Alpha internal consistency coefficient of the scale was 0.89 . The total variance that all the sub-dimensions of the scale accounted for was $19.26 \%$.

The collected data were entered into SPSS 22 and analysed using regression analysis. The correlations between lifelong learning scores and achievement focused motivation scores of the subjects were found and interpreted. Also, the correlations between the total scores of the sub-dimensions of achievement motivation and lifelong learning total scores were demonstrated and interpreted and finally some conclusions were drawn.

\section{Results}

As a result of the regression analysis, the correlations between lifelong learning tendency and achievement focused motivation scores of the university students involved in the study are given in Table 1 below.

Table 1. Correlations between lifelong learning tendency and achievement focused motivation scores

\begin{tabular}{lllllll}
\hline & LLT & AFM & AFM Ext. Eff. & AFM Int. Eff. & AFM Exp. Obj. & AFM Self-Con. \\
\hline LLT & 1,000 & $0,095^{*}$ & $-0,024$ & $0,089^{*}$ & $0,139^{* *}$ & $0,128^{* *}$ \\
AFM & & 1,000 & $0,803^{* *}$ & $0,870^{* *}$ &, $771^{* *}$ & $0,792^{* *}$ \\
AFM Ext. Eff. & & & 1,000 &, $563^{* *}$ &, $495^{* *}$ & $0,490^{* *}$ \\
AFM Int. Eff. & & & 1,000 &, $566^{* *}$ & $0,644^{* *}$ \\
AFM Exp. Obj. & & & & 1,000 & $0,492^{* *}$ \\
AFM Self-Con. & & & & & 1,000
\end{tabular}

*. Correlation is significant at the 0.05 level (2-tailed). $\mathrm{p}<0.05$,

**. Correlation is significant at the 0.01 level (2-tailed). $\mathrm{p}<0.01 \mathrm{~N}=570$

LLT: Lifelong Learning Tendency, AFM: Achievement Focused Motivation

As is seen in the table, there is a positive correlation $(\mathrm{r}=0.095)$ between prospective teachers' achievement motivation and lifelong learning tendency at $95 \%$ confidence interval. It can be asserted that there is a low level relation between the two. As for the correlation between lifelong learning tendency and the sub-dimensions of achievement motivation, lifelong learning tendency has a significant correlation with the expansion of objective $(\mathrm{r}=0,139)$, self-consciousness $(\mathrm{r}=0,128)$ and internal effect $(\mathrm{r}=0,089)$. However, it doesn't correlate significantly with external effect $(\mathrm{r}=-0,024)$. Results of the multiple regression analysis between lifelong learning tendency and achievement focused motivation are shown in Table 2 below.

Table 2. Results of multiple regression analysis on the relation between lifelong learning tendency and sub-dimensions of achievement focused motivation

\begin{tabular}{|c|c|c|c|c|c|c|c|c|}
\hline Model & B & Std. Error & $\beta$ & $\mathrm{t}$ & $\mathrm{p}$ & Zero-order & Partial & VIF \\
\hline 1 (Constant) & 3,297 & 255 & & 12,940 &, 000 & & & \\
\hline AFM Ext. Eff. &,- 232 &, 071 &,- 171 & $-3,284$ & ,001 &,- 024 &,- 137 & 1,608 \\
\hline AFM Int. Eff. &, 019 & ,059 &, 020 &, 328 & ,743 & ,089 &, 014 & 2,156 \\
\hline AFM Exp. Obj. &, 150 &, 052 &, 152 & 2,894 & ,004 & ,139 &, 121 & 1,619 \\
\hline AFM Self-Con. &, 127 & ,057 &, 124 & 2,234 & ,026 &, 128 & ,094 & 1,827 \\
\hline
\end{tabular}

Dependent variable (predicted): lifelong learning tendency

$\mathrm{R}=0.207, \mathrm{R}^{2}=0.043, \mathrm{~F}_{(4,565)}=6.331, \mathrm{p}=0.000$, Durbin-Watson (D.W.) Statistic $=1.810$

As it is observed in Table 2 , the $\mathrm{F}$ value $(6,331)$ and $\mathrm{p}$ value $(0,000<0,05)$ of regression analysis ANOVA table indicate that the model is significant at all levels. $\mathrm{R}^{2}$ value $(0,043)$ demonstrates that the $4,3 \%$ of the change in lifelong learning tendency is accounted for by four sub-dimensions of achievement focused motivation; external effect, internal effect, expansion of objective and self-consciousness. In addition, the Durbin-Watson value $(1,810)$ suggests that there is no autocorrelation in the model. Also, lifelong learning tendency has a constant term of 3,297 without taking into consideration other variables. It is also observed in the research that one unit increase in external effect decreases the value of lifelong learning tendency by 0,232 . In addition, one unit increase in the expansion of objective increases the 
value of lifelong learning tendency by 0,150 , that in self-consciousness by 0,127 and finally the same rise in internal effect by 0,019 .

As the standardised regression coefficient $(\beta)$ indicates, the relative order of importance of predictor values on lifelong learning tendency is as follows; external effect, expansion of objective, self-consciousness and internal effect. It is observed that external effect, expansion of objective and self-consciousness are important predictors for lifelong learning tendency. The fact that the beta value $(\beta=-0.171)$ of external effect is higher than those of other variables with respect to its absolute value makes it a more important predictor for the model compared to other sub-dimensions of achievement motivation. The internal effect variable doesn't have a significant influence on lifelong learning tendency.

Taking into consideration the data given in the regression analysis above, the regression equation (mathematical model) regarding the prediction of lifelong learning tendency is given below:

Lifelong learning tendency = 3,297 - 0,232 x AFM Ext. Eff. + 0,019 x AFM Int. Eff. + 0,150 x AFM Exp. Obj. + 0,127 x AFM Self-Con.

In order to demonstrate whether the relation between the predictor variables and the dependent variable is linear, the scatter plot of the multiple regressions is given in figure 1 below.

Scatterplot

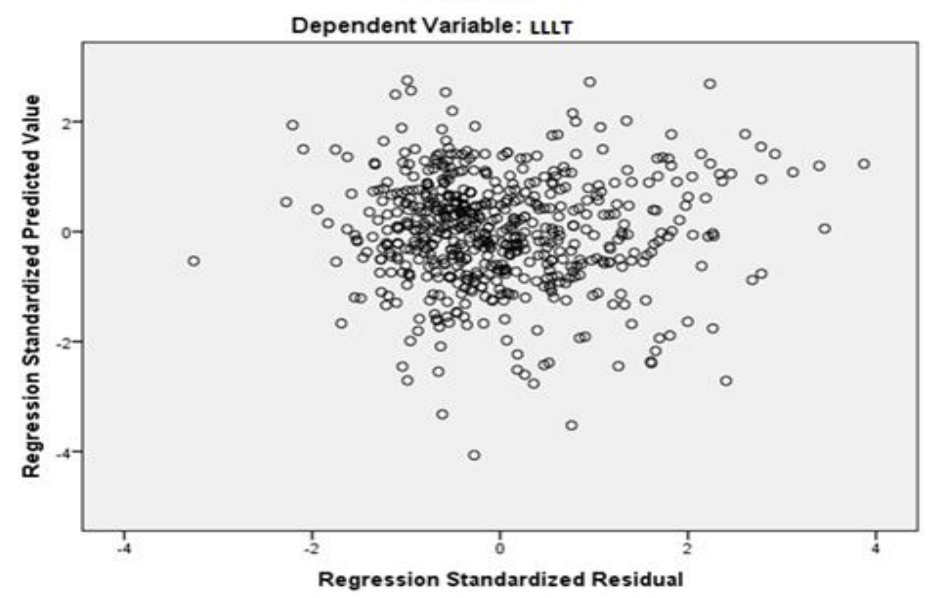

Figure 1. Scatterplot of the predictor and dependent variables

As it is observed in figure 1, the scatter plot demonstrates that the relation between predictor variables and dependent variable is linear and the dots are inclined to gather around an axis. To see whether the distribution of scores is normal, the following histogram and normal probability plot are given together.

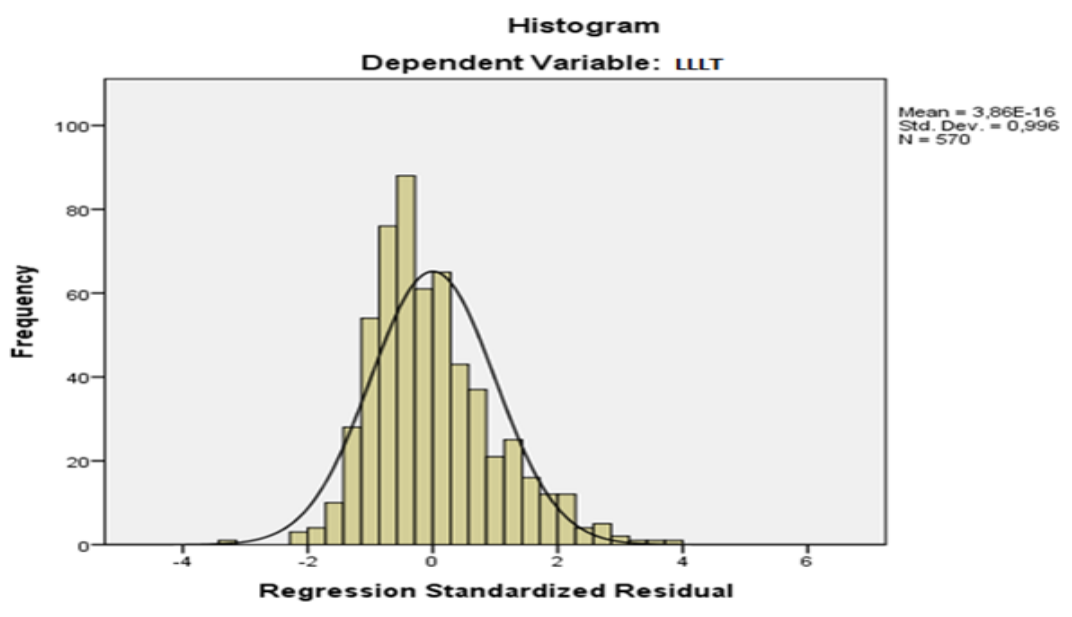

Figure 2. Histogram and normal probability plot regarding the distribution of scores

As can be seen in the above histogram, the scores are distributed normally around zero and standard deviation value is low. 


\section{Discussion}

Lifelong learning and achievement motivation are two important concepts that play a significant role for not only school life but also the acquisition of required survival skills throughout one's life. If an individual is equipped with lifelong learning skills and achievement motivation, s/he will probably succeed in life as the need to learn and succeed will never end. As McCombs (1991) puts it "the motivated person is a lifelong learner and the lifelong learner is a motivated person". Thus, it is useful to have an idea on the relation between these two concepts, which is the aim of this study.

In this study, it was found that there is a low, positive correlation between lifelong learning tendency and achievement motivation scores of the subjects. The correlations between lifelong learning tendency and four sub-dimensions of achievement focused motivation are also low. Only 4,3\% of the change in lifelong learning is accounted for by achievement motivation, which means that lifelong learning tendency is poorly predicted by achievement motivation.

As Pires (2009) suggests, there is a lack of studies on adult learning processes, specifically on adult motivation towards lifelong learning. Therefore, it is hard to find studies focusing on the relationship between lifelong learning and achievement motivation, that is why this study was carried out. However, some scholars such as Timmerman, Toll and Van Luit (2017) prefer to use the term "achievement motivation" instead of "academic motivation" stating that "the majority of studies use the term academic motivation; hence, yet, none provide a clear definition of the term. For this reason, the present study uses the term achievement motivation" (p.92). So, it could be useful to examine the studies focusing on the relationship between academic motivation and lifelong learning so as to have an idea on the relationship between achievement motivation and lifelong learning. One of those studies is the one carried out by Sockalingam et al. on 105 psychiatry residents to examine the relationship between lifelong learning and academic motivation and found significant correlation between lifelong learning and academic motivation. Another study on 3195 subjects in a medical college obtained similar results and significant positive correlations were found between lifelong learning and academic motivation scores as is the case with this study.

Pires (2009) points out that lifelong learning cannot be separated from individuals' motivational dynamics. Lifelong learning is a construct that requires long-term motivation and consciousness. So, these two constructs cannot be evaluated separately. What teachers should do at his stage is to explain the importance of lifelong learning to highly motivated students. Students need to be motivated to a particular extent so as to learn whatever they need to cope with the problems they encounter both at school and their lives. In most cases, however, they are not motivated automatically and they need an external stimulus to act. Most teachers admit that it is their responsibility to motivate their students for the courses they teach. On the other hand, teachers may not assume responsibility to help their students transform into lifelong learners. This may account for the low level correlation between lifelong learning tendency and achievement motivation. Lifelong learning has been gaining importance in recent years and it is regarded as a major goal of contemporary education (Sha, Looi, Chen \& Zhang, 2012), an important and legitimate focus for research activity (Walters, 2008), a source of competitive advantage (Field, 2000), the key solution in overcoming several important social and economic concerns (Ogawa, 2009) and a prerequisite for individual employability and for a lasting increase of the formal qualifications level (Reuling, 2002). All these considerations demonstrate the importance of lifelong learning as well as its multidimensional nature. Taking into account all these realities, more and more schools are expected to include lifelong learning in their curricula and in extracurricular activities. In conclusion, lifelong learning and achievement motivation are two important constructs that play a considerable role in people's lives. So, teachers should stress the importance of lifelong learning for particularly highly motivated learners and the relation between them should be studied using different scales on different samplings, especially on k-12 education.

\section{References}

Asia-Pacific Regional Forum for Lifelong Learning (2004). Lifelong learning in Asia and the Pacific. Bangkok: UNESCO Bangkok.

Bakar, K. A., Tarmizi, R. A., Mahyuddin, R., Elias, H., Wong, S. L., \& Ayub, A. F. M. (2010). Relationships between university students' achievement motivation, attitude and academic performance in Malaysia. Procedia - Social and Behavioral Sciences, 2(2), 4906-4910. https://doi.org/10.1016/j.sbspro.2010.03.793

Commission of the European Communities (2001). Communication from the commission, making a european area of lifelong learning a reality. Brussels: Commission of the European Communities. Retrieved from http://aei.pitt.edu/42878/1/com2001_0678.pdfsummaries/education_training_youth/lifelong_learning/c11054_en.ht $\mathrm{m}$

Coşkun, Y. D., \& Demirel, M. (2010). Lifelong learning tendency scale: the study of validity and reliability. Procedia Social and Behavioral Sciences, 5, 2343-2350. https://doi.org/10.1016/j.sbspro.2010.07.461

Curwin, R. L. (2014). Can assessments motivate. Educational Leadership, 72(1), 38-40. 
Dereli, E., \& Acat, M. B. (2010). Okul öncesi eğitim öğretmenliği bölümü öğrencilerinin motivasyon kaynakları ve sorunları. Selçuk Üniversitesi Sosyal Bilimler Enstitüsü Dergisi, 24, 173-187.

Field, J. (2000). Governing the ungovernable: why lifelong learning policies promise so much yet deliver so little. Educational Management \& Administration, 28(3), 249-261. https://doi.org/10.1177/0263211X000283002

Gagne, F., \& Pere, F. S. (2001). When IQ is controlled, does motivation still predict achievement? Intelligence, 30, 71-100. https://doi.org/10.1016/S0160-2896(01)00068-X

Guthrie, J. T., Wigfield, A., \& VonSecker, C. (2000). Effects of integrated instruction on motivation and strategy use in reading. Journal of Educational Psychology, 92(2), 331-341. https://doi.org/10.1037/0022-0663.92.2.331

Heckhausen, J., \& Heckhausen, H. (2008). Motivation and action. New York: Cambridge University Press. https://doi.org/10.1017/CBO9780511499821

Jarvis, P. (2009). Learning to be a person in society. London, UK: Routledge.

Kaur, S. (2013). Academic achievement in relation to achievement motivation of high school students. International Journal of Science and Research, 2(12), 409-411.

Knapper, C., \& Cropley, A. J. (2000). Lifelong learning in higher education. London: Kogan Page.

Laal, M., \& Salamati, P. (2012). Lifelong learning; why do we need it? Procedia - Social and Behavioral Sciences, 31, 399-403. https://doi.org/10.1016/j.sbspro.2011.12.073

Livingstone, D. W. (2010). Lifelong Learning in Paid and Unpaid Work: Survey and Case Study Findings. London and New York: Routledge.

Martin, G. (2012). Motivation for lifelong learning: a biographical account of efficacy and control. International Journal of Lifelong Education, 31(6), 669-685. https://doi.org/10.1080/02601370.2012.723048

McCombs, B. L. (1991). Motivation and lifelong learning. Educational Psychologist, 20(2), 117-127. https://doi.org/10.1207/s15326985ep2602_4

Ogawa, A. (2009). Japan's new lifelong learning policy: Exploring lessons from the European knowledge economy. International Journal of Lifelong Education, 28(5), 601-614. https://doi.org/10.1080/02601370903190011

Pires, A. L. (2009). Higher education and adult motivation towards lifelong learning: An empirical analysis of university post-graduates perspectives. European Journal of Vocational Training, 46(1), 129-150.

Reuling, J. (2002). Vocational Training and Lifelong Learning in Australia: Observations and conclusions from a German perspective. Vocational Training and Lifelong Learning in Australia and Germany, Adelaïde (NCVER), 14-20.

Schunk, D. H. (2012). Learning theories: An educational perspective. ( $6^{\text {th }}$ edition). Boston: Pearson Education.

Semerci, Ç. (2010). Başarı odaklı motivasyon (BOM) ölçeğinin geliştirilmesi. E-Journal of New World Sciences Academy, 5(4), 2123-2133.

Semerci, Ç., \& Duman, B. (2013). Achievement motivations of the students studying at computer and instructional technologies teaching department. Mevlana International Journal of Education, 3(1), 134-142. https://doi.org/10.13054/mije.13.17.3.1

Sha, L., Looi, C. K., Chen, W., \& Zhang, B. H. (2012). Understanding mobile learning from the perspective of self-regulated learning. Journal of Computer Assisted Learning, 28, 366-378. https://doi.org/10.1111/j.1365-2729.2011.00461.x

Slavin, R. E. (2012). Educational psychology: Theory and practice. N J: Pearson.

Sockalingam, S., Wiljer, D., Yufe, S., Knox, M. K., Fefergrad, M., Silver, I., ... Tekian, A. (2016). The relationship between academic motivation and lifelong learning during residency: A study of psychiatry residents. Academic Medicine, 91(10), 1423-1430. https://doi.org/10.1097/ACM.0000000000001256

Steinmayr, R., \& Spinath, B. (2009). The importance of motivation as a predictor of school achievement. Learning and Individual Differences, 19, 80-90. https://doi.org/10.1016/j.lindif.2008.05.004

Story, P. A., Hart, J. W., Stasson, M. F., \& Mahoney, J. M. (2009). Using two-factor theory of achievement motivation to examine performance-based outcomes and self-regulatory processes. Personality and Individual Differences, 46, 391-395. https://doi.org/10.1016/j.paid.2008.10.023

Timmerman, H. L., Toll, S. W. M., \& Van Luit, J. E. H. (2017). The relation between math self-concept, test and math 
anxiety, achievement motivation and math achievement in 12 to 14-year-old typically developing adolescents. Psychology, Society, and Education, 9(1), 89-103. https://doi.org/10.25115/psye.v9i1.465

Walters, S. (2008). Realizing a lifelong learning higher education institution. In Sutherland and Crowther (Eds.), Lifelong learning: concepts and contexts (pp. 71-81). London and New York: Routledge.

Woolfolk, A. (2013). Educational Psychology. Upper Saddle River, New Jersey: Pearson

Yılmaz, E. (2014). Güçlü yön temelli yaklaşımın yükseköğretimde İngilizce dersinde devam, akademik başarı ve motivasyon üzerindeki etkisinin incelenmesi. Unpublished $\mathrm{PhD}$ Thesis. Firat University, Elazığ.

\section{Copyrights}

Copyright for this article is retained by the author(s), with first publication rights granted to the journal.

This is an open-access article distributed under the terms and conditions of the Creative Commons Attribution license which permits unrestricted use, distribution, and reproduction in any medium, provided the original work is properly cited. 